\title{
'A ella no le gusta que le digan María y a mí que me traten de tú'. A window into Latin American diversity
}

Rosina Márquez Reiter

\begin{abstract}
In this paper I explore sociolinguistic and pragmatic aspects of institutional discourse in a Spanish-speaking modern, mediated and regulated site of talk, namely a telephone conversation gathered at a call centre which had recently been set up in a South American financial hub. I focus on instances of interactional misfires in a service call between a Montevidean institutional agent and a Bogotano client by examining how they unfold, the possible reasons behind them and the implications for (mediated) communication in a globalized world.
\end{abstract}

Keywords: MEDIATED TALK, CALL CENTRE, INTERCULTURAL COMMUNICATION, NEW ECONOMY, BOGOTANO SPANISH, MONTEVIDEAN SPANISH

\begin{abstract}
Affiliation
University of Surrey

Correspondence: Faculty of Arts and Human Sciences, University of Surrey, Guildford GU2 7XH

email: r.marquez-reiter@surrey.ac.uk
\end{abstract}




\section{Introduction}

In this article, I examine sociolinguistic and pragmatic aspects of institutional discourse in a Spanish-speaking modern, mediated and regulated site of talk, namely a telephone conversation gathered at a call centre which had recently been set up in a South American financial hub.

Call centres were introduced in North America and Western Europe in the 1980s. They were pioneered by the financial service sector to centralise dispersed customer service and sales operations and thus minimise costs and maximise profits. The creation of call centres was made possible, amongst other things, by the modern 'global borderless economy' (Ohmae 1995) in which we now live and by the integration of computer and telephone technologies, in particular by the creation of the Automatic Call Distribution system, low cost property availability, regional development policy, tax incentives and skilled labour supplies.

In their early days, call centres were located onshore with national and transnational operations within the major regions of developed economies, albeit generally in regions with relatively high unemployment (e.g. Glasgow in the UK) and relatively cheap labour. It is only relatively recently that call centres have become a truly globalized phenomenon as a result of the technological advances which provide customers with services at a distance, in real time and twenty-four hours a day seven days a week.

As Taylor and Bain put it,

call centres exemplify Castells' informationalism (2000), which, in the context of a networked, globalized economy, replaces the 'space of places' with the 'space of flows', 1 and represents the 'death of distance' (Cairncross, 1997). (2005:262)

However, the very financial sector which pioneered the migration of call centres to the developing world is now questioning the extent to which this 'death of distance' exists as the benefits of offshoring and relocating call centres to developing economies are being challenged under the goal of 'understanding customers' needs'. ${ }^{2}$ Several banks and insurance companies are currently assessing which types of work could be successfully offshored and which should be provided onshore given that certain services such as opening new accounts rather than more routine services such as requiring a statement entail better trained staff with home language skills and a high level of cultural similarity. ${ }^{3}$ Added to this, salary costs in developing market economies such as India are rising and thus some of the financial advantages of offshore call centres are diminishing. Further, lack of cultural similarities and communication difficulties reported in providing nonroutine services can lead to calls taking twice as long as in onshore operations ${ }^{4}$ and, as a result, lower profitability.

The labour requirements of this new economy have created the need for a new type of customer service representative: one that is highly qualified both in terms of linguacultural knowledge and communication skills (i.e. university graduates) (NASSCOM 2005). The choice of university graduates over more traditional customer service representatives, who principally had to deal with customers in intracultural face-to-face interactions, has brought about changes in service provision and in the way customers and service 
representatives interact with one another. This, in turn, helps to partly explain the commonly reported differing expectations between customers and agents at these modern mediated communication spaces. In other words, connecting to remote places in the world can bring to the fore the cultural distance rather than just the physical distance between customers and those who serve them. The cultural distance I am referring to here is nothing less, nothing more than the intercultural communication (Gudykunst 1998) issues which result from the mediated contact between an L1 and an L2 or FL speaker of English (e.g. British customer and an Indian telephone agent) or, in the case that concerns us here, the contact between native speakers of the same broad language who come from different backgrounds.

Call centres were introduced in Latin America at the beginning of the millennium. In the last five to seven years a number of multinational companies with onshore call centres in given Latin American countries have migrated their 'home-based' call centres (e.g. a call centre based in Mexico servicing the needs of Mexican customers) to other Latin American regions which offer state-of-the-art infrastructure and office layouts (e.g. fibre optic connections with key business capitals, exclusive teleport for satellite communication, toll-free 800- numbers from the USA, etc.), better financial incentives (i.e. relatively low salaries and tax incentives) and a more skilled workforce. Several multinational companies have thus set up their headquarters for the Spanish-speaking world in Latin American countries which offer the above mentioned benefits. The case that interests us is precisely the Spanish-speaking operation of a multinational company specialised in offering high standard holiday accommodation for their various Latin American clients. Communication between agents and clients at this call centre is intercultural in that although the conversational participants broadly speaking share a language (i.e. Spanish), they come from different cultural backgrounds and speak different varieties of the same language. Importantly, the multinational nature of the call centre represents a primary occasion for contact between speakers of different varieties of Latin American Spanish, who may otherwise only come in contact with one another through the media, the internet, tourism and/or immigration.

Until now research that has (in)directly focused on intercultural communication in Spanish has principally examined languages in contact. Scholars in this area of inquiry (see, for example, Zimmerman and de Granda 2004) have investigated the intercultural patterns that emerge when Spanish is in contact with other languages; rather than, contact between native speakers of Spanish from different backgrounds. Most studies of intercultural communication have mainly focused on bridging cultural differences (see for example, Gudykunst 1998) that result from differing 'mental programmes' (Hofstede 2001). Owing to the nature of the cultural groups examined, that is, different linguistic and cultural groups who do not share similar communicative norms, the underlying assumption is that many of the communication problems reported in intercultural encounters stem from the lack of a shared native language experience. In this study, however, the participants are both native speakers of the same language and nevertheless, interactional misfires occur. Intercultural communication is thus understood as an instance of interpersonal communication between participants who are culturally different (Scollon and Scollon 1981) but share a broad language in common. They are culturally different in terms of their ethnic composition, languages spoken beyond Spanish, religion, music and 
dance, membership to trading blocks, access to education, socioeconomic performance indicators including poverty index and so on.

Communication between agents and clients at this call centre is institutional in that it is primarily task-oriented. The conversational participants of the call examined in this paper are an institutional representative and a client; the situational context of the call is primarily transactional rather than relational and; the conversational participants' contributions are oriented toward the achievement of a task, namely, the institutional representative wants to obtain a sale and the client wants to obviate any possible avenues for the former to attain her goal. Communication between the conversational participants is monolingual and intercultural. It is monolingual in that it is carried out in the participants' native language (i.e. Spanish) and intercultural given that the participants come from different backgrounds and speak different varieties of the same broad language.

The purpose of this paper is two-fold. First, it seeks to contribute to the study of business interactions and other types of institutional talk in an increasingly globalized world where the mobility of people, circulation of goods and technological advances have given rise to new communicative practices (e.g. mediated service encounters twenty-four hours a day, seven days a week). Second, it aims to inform our understanding of intercultural communication in a contemporary business environment that reflects modern capitalist societal service practices. It does so by offering an analysis of a call centre service call with specific attention to instances of interactional misfires. It examines how they unfold, the possible reasons behind them and the implications for (mediated) communication in a globalized world.

I will begin by presenting the background and methodology of the study. Then I will move onto the analysis of the call selected for this article. The analysis draws on the recorded telephone conversation and other forms of data collected during the fieldwork I conducted at the site. Finally, I present the conclusions of the study.

\section{Background and methodology}

For this study I gathered several kinds of data over a one-month period in 2006. The data for this article is a recorded conversational exchange between an institutional representative, the caller, and a potential client, in this case the called. The caller is a speaker of Montevidean Spanish and the called a speaker of Bogotano Spanish. The telephone conversation analysed is an outbound call which forms part of a large service call database. It was randomly selected from those recorded by the call centre's Operations Department in charge of dealing with Colombian clients. Additionally, the analysis draws on informal interviews I conducted with the caller and the called immediately after the call had taken place and, recorded informal interviews with institutional representatives from the call centre, ${ }^{5}$ reference to other calls within the database and the call centre's training manual for outbound calls, that is, calls made by agents to potential or actual clients.

Both agents and clients are aware of the fact that their calls may be monitored for quality control procedures. Call centre agents were also told that a researcher would be collecting data in situ for the purposes of examining communication in Spanish. Permission was obtained from the company to use the recorded calls, interviews and notes from observations, provided that an appropriate system for the safe custody of confidential information was in place. To this end, a legally binding agreement was signed between the 
parties. Agents were not obliged to participate in the interviews; they did so out of their free will and in all cases I asked permission to record them.

The call centre where the data comes from has circa 300 agents. Each agent is allocated a cubicle. There are 18 agent cubicles per call centre 'island'. Each island deals with a different aspect of the services provided by the company (e.g. renewals, deposits, etc.) At the front of every island sits a team leader with his/her own headset. The team leader is the first port of call should problems arise in the communication between agents and clients. The vast majority of the clients are native speakers of Spanish and come from a variety of countries: Argentina, Bolivia, Colombia, Chile, Ecuador, Mexico, Paraguay, Peru, Uruguay and Venezuela. Due to the nature of the product offered by the company and the socio-economic situation of the countries where the client pool comes from, the clientele tends to belong to the (upper) middle-class stratum within their respective countries of origin.

The agents are native speakers of Latin American Spanish (Lipski 1994). They have completed secondary school and more than a third of them have university degrees, including postgraduate qualifications. Additionally, many of them speak foreign languages such as English, French, Hebrew, Portuguese and Swedish. As such, they represent a highly qualified workforce. From the perspective of this multinational company, the agents' communicative skills are not necessarily based on their ability to speak foreign languages as most communication with the clients is monolingual, but rather on their educational qualifications which should theoretically enable them to be good communicators at a pan Latin American level. Put differently, sameness of language is equated with 'common ground' (Linell 1998) by the communication consultants of the company. Thus, unlike previous research carried out on communication at call centres (see, for example, Budach, Roy and Heller 2003; Friginal 2009; King 2009) what is seen as a commodity, and specifically as far as the Spanish-speaking operation of the company is concerned, ${ }^{6}$ is not the agents' ability to speak foreign languages but their high level of education which would, in theory, ipso facto make them excellent communicators. This is coupled with the agents' need to find work even when this involves low wages, long hours, and in some cases an unhealthy lifestyle due to night shifts, as well as no long-term career prospects within the company. As explained by one of the call centre's agents 'work at the call centre no matter how intensive it may be, represents economic improvement at a personal level and a springboard to other potential jobs at other multinationals'.

Call centre agents are required to attend a six-week training course before they start their work in the call centre. During the training period, agents are given information about the company's product and operations across the world and, in particular, about the Latin American operation. They are also given training in managing calls. Specifically, they are told to follow a script for taking and placing inbound and outbound calls. The prescribed interactional behaviour to be followed by agents in outbound calls is described below:

(1) In-house rules for outbound call openings

1) Greet the (potential) client, provide self and organizational identification and a brief description of the company's business

Buen día, mi nombre es (Nombre y Apellido), y le estoy llamando de Vacaciones Inolvidables Latinoamérica, breve descripción de la compañía 
'Good morning, my name is (first name and surname) and I am calling you ${ }^{\mathrm{U}}$ from Holidays to Remember Latin America, brief description of the company's business

\section{2) Explain the reason for the call}

Le estoy llamando porque tenemos una promoción especialmente para usted...

'I am calling you ${ }^{\mathrm{U}}$ because we have a promotion especially for you ${ }^{\mathrm{U}}$,

\section{3) Establish the client's interest}

Es interesante ¿cierto?, suena atractivo ¿verdad?

'It is interesting, isn't it?', it sounds enticing, doesn’t it?'

The analytical framework I adopt, in line with my recent work on institutional telephone conversations in Spanish (Márquez Reiter 2005, 2006, 2008, 2009), is integrative. I use concepts developed in Conversation Analysis to examine how the opening sequence and other sequences where interactional misfires occur are locallymanaged and sequentially organized and elements of sociolinguistics and pragmatics (e.g. politeness orientations, accommodation, codification of the rules of interaction) to fully account for interactional asymmetries.

\section{Opening the door to communicative success?}

First I focus on the general structure of the call opening, providing both a context-internal and context-external discussion of how it unfolds given that although talk is jointly accomplished, the call centre's agents are meant to follow the company's script. I then focus more closely on some of the verbal elements within the opening sequences and the pre-closing sequence in which interactional misfires are observed.

(2) The opening, lines 1-25

C: client

T: telephone agent

NB: Although the names of the participants and of the company are fictitious, the first name of the client is real.

1 C: Aló.

'Hello'

2 T: Buenas tardes. hablo con el doctor Segundo Gómez?

‘Good afternoon.am I speaking to doctor Second Gómez? 
3 c: Con quién ha:blo:?

'Who is speaking?

4 T: E:::h le está hablando de Juana Camiglia de Vacaciones Inolvidables (.) desde (país donde está ubicado el call centre) (.) cómo está usted docto:r?(.)

'Um Juana Camiglia is speaking from Holidays to Remember (.) from (country where the call centre is located) $\downarrow$ how are you doctor?'

5 C: Bie:nseñora.

'Finema' am'.

6 T: Cómo ha pasado:?

'How have youu been?'

7 C: Bie:n. bienbien.

'fine. finefine.'

8 T: Están descansando ya que es día festi:vo:?

'Are you relaxing as it's a bank holiday?'

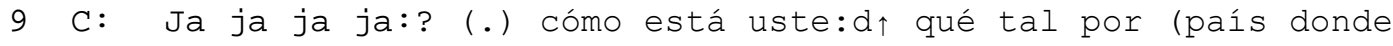
está ubicado el call centre)?

'Ha ha ha ha ?(.) how are youu $\uparrow$ how are things (country where the call centre is located)' ?

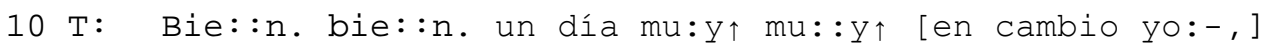

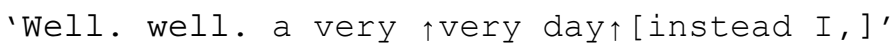

11 C: [Cómo está el cli:ma:?] yo estoy-. estoy aquí en Colombia en un día muy lluvio:so: lluvio:so $\downarrow=$

'[What is the weather like?] I am. am here in Colombia on a very rainy day. rainy. $=$ '

$12 \mathrm{~T}:=$ =No me di:ga:? desde la semana pasada están así con ese clima verda: d?

'=Really? you have been having this weather since last week right?

$13 \quad(.3)$

14 T: Segu: ndo:?

'Second?' (client's first name)

$15(.2)$

16 C: Sí:dígame: . 
'Yestell' me.'

$17 \mathrm{~T}$ : Desde la semana pasada que están con el mismo clima, que ha llovido prácticamente toda la semana pasada, verda:d?=

'Since last week you have been having the same weather it has been raining practically all last week, right?='

18 C: =A: :llá: : .=

$'=$ There. $=$ '

19 T: No: : aquí por suerte no: porque como estamos entrando ya en la primavera como que el clima e:h es este::, está siendo má::s? [más (¿ ?) - . ]

'No.= here luckily no because we are already entering into spring as the weather is um like um, it is being more ? [more (?). $]^{\prime}$

20 C: [Esta:ble esta:]ble?=

'[Stable sta]ble?='

$21 \mathrm{~T}:=$ Sí: .

$'=$ Yes.'

22 C: A: : : hbue: no.

'AhOK.'

$23 \mathrm{~T}$ : SeñorSegundo. permítame uno:s e:ste: :? unos minutitos para poder confirmar con usted algunos datos personales,

'MrSecond. allow' me a few um? a few minutes to confirm with you ${ }^{u}$ some personal details,'

\section{$24 \quad(.2)$}

25 C: [Ahá: . ]

'[Aha. ]'

The opening of the call with the Bogotano client is typical of first attempt rather than follow up outbound calls with actual clients, particularly those calls made by Montevidean agents. Although the agent greets the client at line 2, she does not follow the company's script in that she does not provide self-identification, organizational identification or a brief description of the company's business. Instead, the agent's first effort is directed at identifying the account holder or in the words of Sacks (1992) establishing whether 'the answerer' is indeed 'the called' in order to maximise her time over the phone. This manoeuvre was confirmed in the post-performance interview with the agent. During the interview the agent explained that although they are meant to follow a script and are, theoretically, constantly being monitored, the script for the openings is rather long-winded and pre-empts the element of surprise that salespersons need in unsolicited transactional calls in order to avoid an early declination. I shall return to this point in the second part of 
the analysis (see section 3.2). The agent added that the team leader of her island is far too busy taking calls himself/herself to be monitoring the language that agents use. Instead, the team leader is primarily interested in meeting call targets, that is, the number of calls processed by his/her team and the time the team spends on each call.

The 'uninformativeness' (see section 2, in-house rules for opening outbound calls) of the agent's first turn triggers the client's request for identification at line 3 , as shown in example (3).

(3) The opening, lines 1-5

1 C: Aló.

'Hello'

2 T: Buenas tardes. hablo con el doctor Segundo Gómez?

‘Good afternoon.am I speaking to doctor Second Gómez?

3 C: Con quién ha:blo:?

'Who is speaking?

4 T: E:::h le está hablando de Juana Camiglia de Vacaciones

Inolvidables (.) desde (país donde está ubicado el call

centre) (.) cómo está usted docto:r?(.)

‘Um Juana Camiglia is speaking from Holidays to Remember (.)

from (country where the call centre is located) $\downarrow$ how are you ${ }^{u}$ doctor?'

5 C: Bie:nseñora.

'Finema' am' .

The agent does so at line 4 in a turn which comprises four turn-constructional units (Sacks, Schegloff and Jefferson 1974), namely self-identification, organizational identification, localization and the first pair part of a 'how are you exchange'. Neither the location of the call centre nor the 'how are you exchange' are prescribed by the company. Moreover, these two sequences are non-canonical in that, strictly speaking, they are not essential for the transaction to take place. Support for this can be observed in the micro pause which precedes these two units, thus potentially implicating a response from the client and making the proffering of localization and the first pair part of a 'how are you exchange' contingent upon lack of client's uptake.

Nonetheless, localization ${ }^{7}$ is frequent in outbound calls, particularly with those clients who had not made of use of their membership since the various Latin American call centres were centralised. As such, localization is relevant as it helps to account for the 'foreignness' of the agent and to remind the client that services for the Colombian clientele are now provided from a different country. The 'how are you exchange' is also optional. 
However, it occurs in all first attempt outbound calls within the database, thus reflecting an expected social practice amongst Latin Americans (see Márquez Reiter 2006, 2009).

Sociopragmatically speaking, the sequence is formulated according to the house style norms in the sense that the client is formally and deferentially addressed. This is observed by the overt inclusion of the formal second person singular usted and the occurrence of the deferential title doctor. In the River Plate variety of Spanish spoken by the agent, subject pronouns are not included given that the conjugation of the verb suffices to mark a formal v. informal distinction. Despite the fact that the company's records indicate that the client is a Doctor in medicine, according to the agents and to my own experience as a native speaker of River Plate Spanish, such titles are only employed when one is dealing with one's doctor or lawyer and not with a client whose professional qualifications are irrelevant to the sale in question. Its inclusion is a case of linguistic accommodation. The agent strategically converges to what she predicts, on the basis of her experience of working with both Bogotano clients and colleagues, is expected from her so as to improve communication effectiveness (Giles, Coupland and Coupland 1991) and thus enhance her chances of attaining her conversational goal: a sale.

The client responds at line 5 with the second pair part of the 'how are you exchange' uttered with descending tone and including the term señora. The occurrence of the second pair part of the 'how are you exchange' is four-fold. First, it confirms the information contained in the previous turn, in this case recognition of the organization on whose behalf the call is being made. Second, it functions as response to the 'how are you exchange' initiated by the agent. Third, given its descending tone and its sequential placement, that is, after the identification and recognition sequence (Márquez Reiter 2006), it signals a transition relevance place in which the client expects to be given the reason for the call. The inclusion of terms such as señora is typical of interactions with Bogotanos. According to some of the interviews conducted with Bogotano agents, the inclusion of such terms signals the respectful distance that one is expected to give in interactions with strangers regardless of their status.

Given the lack of effusiveness of the client's answer (i.e. constructed by means of an unintensified discourse marker with descending tone), the agent initiates a stretch of small talk at line 6. During the post-performance interview, the agent justified the need for small talk as a means of ingratiating herself with the client given that "Colombians, and particularly Bogotanos, are very formal and dry". The instantiation of small talk is, therefore, aimed at reducing the distance with the client and is in line with agent's contributions so far (i.e. the presence of the first pair part of a 'how are you exchange' when a formal greeting such as Buenas tardes doctor could have been offered instead). It seeks 'intimacy at a distance' (Hutchby, 2001), especially given the telephone mediated nature of the interaction which affords the conversational participants the 'possibility of interactional co-presence without physical co-presence' (Hutchby 2001:108). The beginning of small talk occurs in the anchor position (Schegloff, 1986), that is, at the first available opportunity for the caller to give the reason of the call.

The client responds to the agent's initiation of small talk at line 7 with a turn comprising the discourse marker bien followed by the consecutive repetition of this marker with descending tone, as shown below.

(4) The opening, lines 4-11 
4 T: E:::h le está hablando de Juana Camiglia de Vacaciones Inolvidables (.) desde (país donde está ubicado el call centre) (.) cómo está usted docto:r?(.)

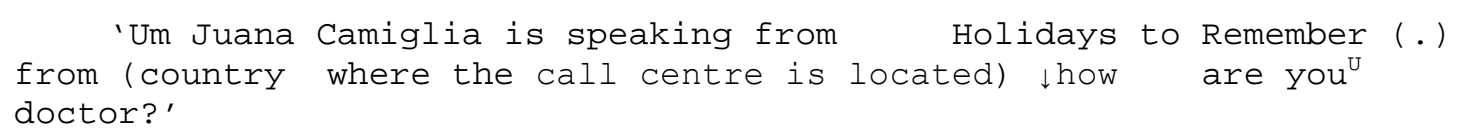

In doing so, he implicitly requests that the agent offer the reason for the call and reconstructs the anchor position. Despite the client's lack of interpersonal involvement, the agent continues with the small talk. This time, however, the agent shows that in spite of the physical and dialect distance that separates them, she is informed about everyday life in Colombia. This is observed at line 8 in which the agent demonstrates her knowledge of Colombian bank holidays. As shown at line 9, the agent's conversational manoeuvre pays off in that it triggers the client's laughter and an exchange of 'how are yous', albeit this time proffered by the client, thus showing the routinised character of the 'how are you exchange' offered by the agent at line 4 .

In line with the relatively verbose communicative style of some Montevidean service providers (see, for example, Márquez Reiter and Placencia 2004 and Márquez Reiter 2006, 2008), which is evidenced here by the length of the opening, and in the light of the 'how are you exchange' volunteered by the client, the agent does not offer the reason for the call 
where it is potentially possible and expected. Instead, and as observed at line 10, she interlocks (Schegloff 1986) the second pair part of the 'how are you' exchange with the introduction of a characteristic topic of small talk: the weather. The client responds via the consecutive repetition of the adjective lluvioso ('rainy') with pitch rise and descending tone. In doing so, he signals again a transition relevance place in which he expects the agent to offer the reason for the call. The agent, however, continues to inquire about the weather in the client's location by means of a latched turn uttered with rising intonation. The agent thus shows her 'strategic' interest in engaging in small talk and the fact that this type of conversational behaviour is seen by her as a 'normal' preamble to the sales process, even in those cases in which the participants do not know each other. Further support for this was found in the interview conducted with the agent where she explained that así les entrás, ¿no? ('this is how you get close to them, right?'). The client's reaction, however, as observed at line 13 below by his dispreferred response constructed by means of a pause of 0.3 seconds, reflects his disinterest, surprise or even lack of understanding of what the agent is saying.

(5) The opening, lines 12-25

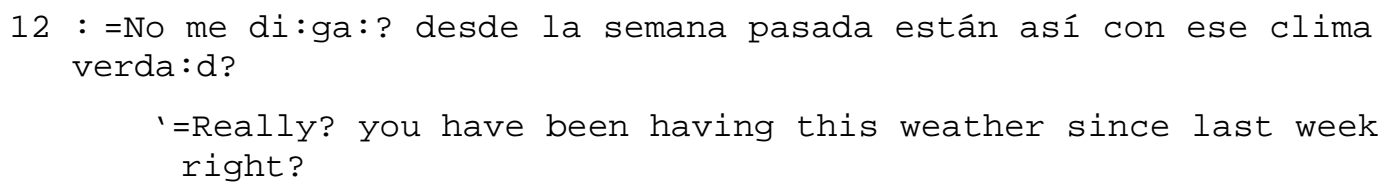

14 T: Segu:ndo:?

'Second?' (client's first name)

$15 \quad(.2)$

16 C: Sí:dígame: .

'Yestell' me.'

$17 \mathrm{~T}$ : Desde la semana pasada que están con el mismo clima, que ha llovido prácticamente toda la semana pasada, verda:d?=

'Since last week you have been having the same weather it has been raining practically all last week, right?='

18 C: =A: :llá: : :=

$‘=$ There. $={ }^{\prime}$

19 T: No: : aquí por suerte no: porque como estamos entrando ya en la primavera como que el clima e:h es este::, está siendo má::s? [más (¿ ?) - - ]

'No.= here luckily no because we are already entering into spring as the weather is um like um, it is being more ? [more (?). $]^{\prime}$ 
$20 \mathrm{C}: \quad[$ Esta:ble esta:]ble?=

'[Stable sta]ble?='

$21 \mathrm{~T}:$ =Sí: .

$'=$ Yes..

22 C: A: : : hbue: no.

'AhOK.'

$23 \mathrm{~T}$ : SeñorSegundo. permítame uno:s e:ste: :? unos minutitos para poder confirmar con usted algunos datos personales,

'MrSecond. allow' me a few um? a few minutes to confirm with you some personal details,'

$24 \quad(.2)$

25 C: [Ahá: .]

'[Aha. ]'

According to some of the interviews conducted with Colombian team leaders, Bogotanos do not usually engage in small talk in unsolicited transactional calls with strangers. In spite of the client's dispreferred response and his minimal responses at lines 18 and 20, the agent continues talking about the weather until line 22 where the client produces a warrant with descending tone (A::h bueno 'Ah alright'). In doing so, the client indicates a shift of direction in the conversation. This is finally interpreted as such by the agent who proceeds to offer the reason for the call. The reason for the call is, however, strategically disguised as a contingency question and not truly offered until line 32.

After checking the client's details from line 23 to 31, at line 32 the agent starts offering the real reason for the call as shown below.

(6) lines 23-32

23 T: Señor Segundo. permítame uno:s e:ste: :? unos minutitos para poder confirmar con usted algunos datos personales.

'Mr Second. let ${ }^{u}$ me have some um::? some minutes ${ }^{\text {dim }}$ to confirm with you" some personal details'

$26 \quad(.2)$

27 C: [Ahá: .]

28 T: [Su domi]cilio es? su dirección es X. ( $i$ ?). Bogotá: . verda: : d? 
'[your ${ }^{U}$ addr] ess is? your ${ }^{U}$ address is $X \downarrow$ (i ?) $\downarrow$ Bogotá: .
right?'

29 C: Síseñora.

'yesma' am'.

30 T: Perfe:cto. y su dirección de e-mail e:s X?

'perfect. and your ${ }^{U}$ email address is $X$ ?'

31 C: 0:key. sí: [el e-mail] el e-mail e:se: es mío.=

'okay. yes. [the email] that email is mine $\downarrow=$ '

$32 \mathrm{~T}:$ [Okey.] =a: : h bueno. okey, perfe:cto, '[okey] =ah fine. okey, perfect,'

$33(.2)$

34 T: Señor Segundo más que nada lo estábamos. bueno llamando:, tengo aquí registrado que ya en alguna oportunidad se han comunicado con uste: d verda:d?=

'Mr Second more than anything we were. well calling you". I have registered here that they have already been in touch with you ${ }^{u}$ right?='

The client responds by suggesting that the agent should contact his spouse and/or daughter (see Appendix A). This strategy is known by the call centre's agents as the Colombian way of 'passing the buck' and is reiterated by the client at line 35 (hágalo por el e-mail de mi hija que es con ella con quien 'do ${ }^{\mathrm{U}}$ it via my daughter's email it is with her with whom'), line 39 (mi hija está en plan de viajar por favor lláme al $X$ 'my daughter has plans to travel please call ${ }^{\mathrm{U}} \mathrm{X}^{\prime}$ '), line 45 (mi hija y mi señora son quienes van a viajar 'my daughter and my wife are the ones who are going to travel'), line 47 ( $a$ las once de la mañana ahí a ese teléfono llamelé 'at 11 o'clock in the morning there to that telephone $\mathrm{call}^{\mathrm{U}}$ her') and line 61 (ellas están en plan de viaje 'they are planning to travel'). Although not within the scope of this paper, the way in which the strategy is formulated and the place within the conversation in which it occurs indicates that this is a pre-closing sequence. It is worth noting, however, that according to the company's rules even if the client's wife or daughter wanted to book the service intended to be sold, the agent would need to seek authorisation from the account holder, in this case, from Mr Segundo himself.

Having provided a structural analysis of how instances of interactional misfires unfold in the conversation, I will now examine sociolinguistic and pragmatic aspects of some of the verbal units within the sequential turns examined.

\subsection{Whose language, whose norms?}

When placing calls, agents are required to respectfully greet the answerer and to provide self and organizational identification before they can proceed to the reason of the call. In line with the company's global image and the relatively recent centralisation of its various 
Latin American operations into one centre, agents are also required to provide a brief description of the company's business when placing calls. These sequences are, however, locally adapted to the Latin American market as evidenced by the prescribed precedence of non-canonical relational elements (greetings, self-identification) over merely transactional ones (organizational identification) (Márquez Reiter 2006). Although not part of the written in-house rules for outbound calls, as part of the agents' professional socialization, which has been inculcated through training courses and reinforced by the agents' own experiences of seeing other colleagues handling calls and of working with a variety of Latin American clients and fellow colleagues, they are advised to convey a deferential attitude towards clients. They are told to treat all clients formally (i.e. usted) and to address them by their professional titles (i.e. Dr) when appropriate. When the company's records indicate that clients do not have any professional titles, agents are told to address them by the polite Don/Doña ('Mr/Mrs') followed by their first names and/or surnames, even in those cases where the clients specifically ask to be treated informally. ${ }^{8}$

The inclusion and precedence of non-canonical relational elements (greetings, self identification) over canonical transactional ones (organizational identification) underpins a general Latin American interpersonal orientation (Daskal Albert 1996) where the expression of simpatía is emphasised (Márquez Reiter 2006). Likewise, the inclusion of titles underlies a supposedly pan Latin American notion of 'respect' (Fitch 1998). This form of respect does not necessarily address considerations of space but given social power and social distance differences between the participants and is conveyed by deferential expressions (e.g. the use of titles).

It would thus seem that the call centre's script for placing calls closely mirrors the rules of standard written Spanish whereby the second person singular (tú) is employed in relationships where there is confianza and/or intimacy, while usted is reserved for those relationships where the above mentioned characteristics are absent. ${ }^{9}$ The opening sequences which have been codified by the communication consultants of this multinational company draw explicit attention to interpersonal and politeness requirements. We may therefore ask ourselves whose requirements these are. Do they apply to all the different spoken Latin American varieties of Spanish of the company's clients and agents? Clearly not, as evidenced, among others, by the wealth of research that has been undertaken into the interpersonal and politeness orientations of several Latin Americans cultures (see, for example, Fitch 1991 for Colombia and the now numerous publications from EDICE www.edice.org) and by the analysis that follows this brief discussion. So, whose standards are these? I argue that they are the company's. They are motivated by the company's interest in presenting itself in a particular light: as having a respectful, deferential, customer-oriented attitude. This projected company's image stands in stark contrast with its aggressive sales operations which comprises, among other things, first, second and third attempt unsolicited call to prospective and/or actual clients in order to sell them a service that they may not want.

While this formal and deferential attitude sits well with some of its urban clients, particularly with those from Bogota, Lima, Mexico City, Quito and Santiago, according to some of the interviews carried out and, in the light of some of the metacomments found in other calls within the database (see Márquez Reiter 2009), some of the verbal elements of the prescribed sequences (i.e. use of titles) are perceived as arcane by agents from Buenos Aires, Caracas and Montevideo as well as by clients from the same capital cities. Research 
into the politeness orientations of these Latin American varieties of Spanish (see, for example, Márquez Reiter and Placencia 2005) indicates that the latter group shows more of an orientation towards interdependence and affiliation. On the other hand, studies undertaken into the politeness orientation of the former varieties of Spanish have reported that both an orientation towards independence and interdependence are equally sought. Further support for this has been observed in the conversational exchange examined here. The Montevidean agent strategically deviates from the in-house rules to get closer to the client and, in doing so, attempts to construct a symmetrical temporary relationship with her interlocutor, thus subverting the habitual social order, which according to the Colombian agents of the call centre interviewed, characterizes these types of interactions in Colombia. The Bogotano client's contributions, on the other hand, reflect a need for 'hierarchical closeness', that is, temporary closeness with a previously unknown agent which reflects both simpatía and respect. This notion of respect, as remarked earlier, is mainly enacted by the maintenance of the given social power and social distance differences between him and the agent and do not appear to be open to negotiation, at least in the eyes of the Colombian client and in those of the call centre's Colombian employees.

During the interviews conducted, Colombian agents explained that 'the correct way of addressing clients is usted'. They added that 'titles such as Don/Doña are normally deployed' and that 'when these are absent señor/a are used instead'. When I asked a Bogotano team leader why this was the case, rather perplexedly he explained:

Y porque uno es empleado y el otro cliente y eso ya está, hay que ser respetuoso.

'And because one is an employee and the other one a client and that is it, one has to be respectful.'

Possibly as a result of my asking such an 'obvious' question and my distinct River Plate Spanish accent, together with the fact that I was conducting a study of the call centre which helped to legitimate my query, he added:

Qué pena, pero no se lo tome a mal Señora, pero es que aquí la gente hace cualquier cosa. No respetan las jerarquías, vuelven tarde de los breaks y le dicen a uno nomás ‘es que me quedé fumando afuera’ como si ésto los absolviera de pecado.

'Forgive me but don't take this the wrong way Ma'am, but here people do anything they like. They don't respect hierarchies, they come back late from their breaks and simply say "I stayed outside smoking" as if this would absolve them from sin.'

On the other hand, non-Colombian agents who work with Colombian colleagues and clients and especially with Bogotanos explained that they are 'nice though formal' and that this formality possibly stems from 'differences between Colombians'. The differences the agents were alluding to are hierarchical and based on a highly stratified society where the 
traditionally rich families of Spanish descent have benefited from the country's riches (e.g. gold, emeralds, coal) to a greater degree than the majority mixed-raced population (i.e. mestizo 58\%, mulatto 14\%, zambo 3\%; cf UN demographic information for Latin America). These same families have privileged access to other forms of capital including education. It is not uncommon for those who belong to the high class to graduate from an American or European university whereas the lower middle-class may simply not go further than secondary school and the poor no further than primary school, particularly in rural areas (Ministerio de Educación Nacional de Colombia, www.mineducacion.gov.co). With this in mind, I argue that Mr Segundo assumes that he is not talking to an equal given that someone from the same social class would not normally work in a call centre and, if she/he did, she/he would know better than to treat clients disrespectfully.

While hierarchical differences are common across Latin America, the country where the agent comes from is, relatively speaking, more egalitarian. Uruguay has traditionally been better off than many other Latin American countries. It has an advanced education system where education is free at all levels (primary, secondary and tertiary) and has one of the first social welfare systems on the continent. Most Uruguayans are of European descent, chiefly Spanish and Italian. The country has a large middle class and is largely free of serious income inequality relative to Colombia and to other Latin American countries (cf. the UN income inequality metrics and poverty index). The minority (10\%) who are of mixed race, mostly mulatto (4\%- cf. UN demographic information for Latin America) are coincidentally the poorest. The orientation towards egalitarianism is possibly the result of its colonial past, ethnic composition, education system and socialist policies. ${ }^{10}$ In view of the above, the comments made by the Uruguayan agent as to the hierarchical differences between her culture and that of the client should not come as a surprise. The agent is a university graduate who had access to free education, the same education that fellow Uruguayans in privileged socioeconomic positions seek. While the agent may not earn enough money per annum to qualify as a member of the (upper) middle class, this, more than any other factor (e.g. ethnicity, education) is what stops her from gaining membership to that particular segment of Uruguayan society.

Agents are thus required to present themselves in the way the company determines even when this is seen by some of them as alien and demeaning. This is especially so in the case of many of the Montevidean agents whose variety of spoken Spanish, among other cultural factors, precludes them from using titles such as 'Dr' or licenciado ('graduate' or 'doctor' depending on the variety of Spanish) when dealing with a client whose professional qualifications have no relevance to the sale in question. As remarked earlier (see section 2), a large number of the Montevidean agents are university graduates and, in many cases, have more educational qualifications than the clients themselves. A case in point emerged in an interview conducted with a Montevidean female agent who works with Mexican clients. During the interview, the agent reported an interaction in which she formally addressed a client from Mexico City as Sr. González ('Mr González') and was specifically told by the client to address him as Licenciado González ('Graduate González'). The agent reported that she was offended by his request given that she thought she had been sufficiently polite (i.e. inclusion of the title Sr. before the client's surname) and that she herself was a licenciada en enfermería ('graduate in nursing') and was, at the time of the call, in the second year of a Masters degree in nursing. She added that, 
according to the company’s records, Mr González is not a licenciado ('graduate'). ${ }^{11}$ In her own words:

es simplemente mexicano y estos super machos quieren que se los trate así, se largan pedos más grandes que sus culos.

'he is simply Mexican and these super machos like to be addressed like that, their farts are bigger than their arses.'

Control over the stylistic practices of the agents is unsuccessfully exercised by the company's codification of the manner in which calls should be handled in the interest of projecting a homogeneous professional persona across the world. Instead, it is the client who defines what type of communicative behaviour counts as legitimate and this, as I have shown through the interviews, is often resisted by some of the agents. Other agents, on the other hand, are simply resigned to endure overt demonstrations of unequal access to resources (see Márquez Reiter 2009), in this case economic ones, in order to make ends meet. Although it can be argued that most private (mediated) service encounters represent cases of asymmetrical discourse in the sense that it is the institutional representative's responsibility to conduct himself/herself in accordance with the company's rules and the customers' wishes, as Cameron (2008) argues, in top-down talk of the kind examined here

there is a specific and arguably more extreme form of asymmetry in operation, in that the institutional representative is not just making use of a generalized template or schema for service interaction, but is orienting to detailed and sometimes arcane prescriptions which - unlike the overall template or schema - are unlikely to be part of the interlocutor's background knowledge’ (p.153)

An example of this is the use of deferential titles such as 'Dr' and Licenciado ('graduate') when, strictly speaking and from the point of view of some of the Montevidean agents interviewed, this might be irrelevant to the sale in question given that neither medical nor legal issues are the object of the call. While an explicit demonstration of one's educational credentials may be indicative of social class in certain Latin American countries, this is not necessarily so in the country where the telephone agent comes from(i.e. Uruguay) or indeed applicable to the highly qualified work force of the call centre (see section 1)

Let us now return to the conversation selected for this article to see the type of interactional asymmetries that unfold. Specifically, to the client's dispreferred response at line 13 which is reproduced below:

(7) lines 12-16

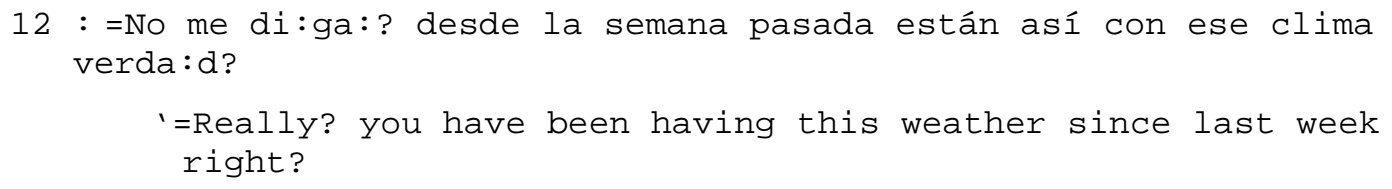




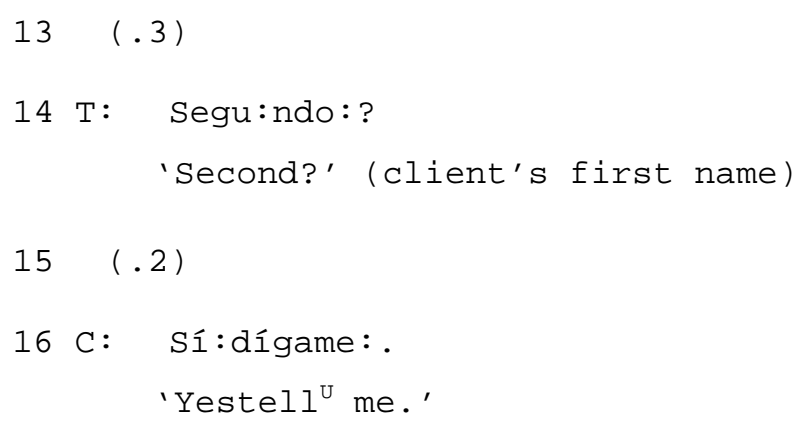

We can observe that the client's dispreferred response constructed by means of silence (i.e. 0.3 seconds pause) as a reaction to the agent's insistence on small talk, is not interpreted as such by the agent. Instead, the client's silence is interpreted as a possible technical problem with the line. This is evidenced by the agent's elliptical request at line 14 aimed at establishing whether the client is still on line. The agent does so by uttering the client's first name with rising intonation. The agent thus shows that she is not aware of the fact that small talk may be seen as inappropriate and unexpected conversational behaviour in first effort calls with Bogotano clients with whom the agent has had no previous contact. This first interactional asymmetry is arguably the result of a lack of 'shared background' (see, for example, Tyler 1995). It reflects a different orientation to the cultural and institutional features of the call in question. The agent appears to regard small talk with a client with whom she has no previous contact as appropriate interpersonal behaviour, whereas the client seems to be taken aback by its occurrence given the social distance between the participants as well as the physical distance (i.e. remote mediated interaction).

Owing to the semantic and in this case contextual ambiguity of the client's first name (Segundo 'Second'), the fact that Bogotano clients expect to be treated by usted and, preferably, deferentially by means of their professional title such as doctor ('doctor') or a polite title such as Don ('Mr') followed by their first name and/or surname, and the ascending melodic curve of the River Plate Spanish of the agent, the client interprets the agent's request at line 14 as a request to hold the line. Support for this can be found in the client's pause at line 15 followed by his acknowledgment at line 16 where he appears to have realised the pragmatic force of the agent's turn at line 14. He thus confirms that he is still on line, can hear the agent and reconstructs the anchor position (Sí dígame 'Yes, tell ${ }^{\mathrm{U}}$ me'), albeit to no avail as the agent continues to talk about the weather. The asymmetry observed here responds to the different politeness orientations of the participants. The agent's contributions are oriented towards seeking closeness (Márquez Reiter and Placencia 2004; Márquez Reiter 2006) in an effort to reduce the social distance between her and the client and thus, in her view, enhance her chances of obtaining her conversational goal. On the other hand, the client expects that the existing social distance between him and the agent be maintained as this would reflect the respectful distance (see Márquez Reiter and Placencia, 2004), that according to him, should be observed in primarily transactional and unsolicited calls with strangers. 
A further interactional misfire can be observed during the instantiation of the client's 'pass the buck' strategy, in his effort to bring the conversation to a close and get rid of the agent. The sequence is reproduced in example (8).

(8) lines 46-57

T: Y tu señora e:h pé- e:h-. ahí-. está con usted [para que yo pueda hablar] con e:lla:?=

'And your' wife um bu bu um. there. is with you' [so that I can speak] to her?='

C: [También ( $i$ ?).] =a las once de la mañana ahí a ese teléfono llamelé:. al que usted [tiene dedicado allí-.]

'[Also (?).] =at 11 in the morning there at that telephone $\mathrm{call}^{\mathrm{u}}$ her:. to the one you ${ }^{\mathrm{u}}$ [have there in your records.]'

T: [No::- yo las puedo llamar a partir de la una de la tarde de Colombia.

'[No-.I can call them from one o'clock in the afternoon Colombian time.'

C: Es correcto. es corre: :cto. sí señora.

'That's fine. that's fine. yes ma'am.'

T: Las puedo ubicar en este telé: fo:no:?

'Can I reach them at that number?'

c: Client gives the telephone number=

T: [Por e:so.] =por eso:. tu esposa es María Gómez verda: :d?

'[That's why.] = that's why. your $^{\top}$ wife is Maria Gómez right?'

C: E:: :-. e:s corre:cto, corre:cto, María Gla:dys, y por favor anótele. $=$

'Um/ that is correct, correct, Maria Gladys, and please write it down. $={ }^{\prime}$

54 T: =Sí: .

'=Yes.'

55 C: Es que a ella no le gusta que le llamen. que le digan María, y a mí que me traten de tú

'It's that she doesn't like to be called. to be called Maria, and I don't like to be treated by you ${ }^{\top}$

56 T: Disculpe doctor Segundo(.) Digamé cómo es el nombre. 
'My apologies to you' doctor Second(.) Tell' me what is the

C: María Gladys Gómez.

'Maria Gladys Gómez.'

As can be seen at line 46, after the false start on perdón (pe-e:h) the agent inadvertently switches from the formal second person singular (usted) to the informal second person singular (tú). The agent code-switches again at line 52 when uttering the first part of a question-answer sequence aimed at confirming the name of the client's spouse tu esposa es María Gladys verdad ('your' ${ }^{\mathrm{T}}$ wife is María Gladys right'). The client reacts at line 53 by confirming the information requested by the agent and explicitly requests to be treated formally. This is done by means of an imperative (anótele 'write ${ }^{\mathrm{U}}$ it down') mitigated by the politeness marker por favor ('please') and further downgraded by a justification (Scott and Lyman 1968) at line 55. The client explains that his spouse likes to be called María Gladys rather than simply María. In other words, he corrects the company's records in the sense that his spouse's first name is María Gladys and not simply María. He further adds that he likes to be addressed by usted (es que a ella no le gusta que le llaman - que le digan María y a mí que me traten de tú 'it's that she doesn't like to be called - to be called María and I don't like to be treated by you ${ }^{\mathrm{T}}$ ). The interactional misfire that takes places in this sequence also stems from the different interpersonal and politeness orientations discussed above. The fact that the client's request constitutes a metapragmatic act makes it more poignant and triggers the deferential apology uttered by the agent in the subsequent turn Disculpe doctor Segundo ('My apologies to you ${ }^{\mathrm{U}}$ doctor Segundo'). Thomas (1985:767) explains that through metapragmatic acts 'dominant participants make explicit reference to the intended pragmatic force of their own or their subordinate's utterances'. Additionally, the client's contribution reflects what he expects and considers appropriate behaviour (Caffi 1998) from an institutional representative in an unsolicited transactional call between strangers.

Further support for this was found in the interview conducted with the client after the call had taken place. The client justified his 'pass the buck' strategy out of pity and politeness considerations by saying:

Qué pena señorita pero soy un hombre muy ocupado y esta gente llama constantemente pero bueno están ganándose la vida.

'What a shame Miss but I'm a very busy man and these people are constantly calling but well they are earning a living.'

The client's comment underlies the importance that politeness considerations seem to have over time concerns in Latin America (see Márquez Reiter 2009) and can explain why he did not put the phone down as soon as he realized that he was trying to be sold a service he did not want. As for the agent's inadvertent code-switch from the formal to the informal second person singular, he said:

Fíjese señora que la muchacha me hablaba como si fuéramos amigos de toda la vida... es una falta de respeto señora, hasta mi madre me habla de usted. 
'look ${ }^{\mathrm{u}}$ ma'am the girl was talking to me as if we were life-long friends... it's a lack of respect, even my mother addresses me by you ${ }^{\mathrm{U}}$.'

This last remark reflects the client's own Spanish social norms which dictate what is deemed appropriate or inappropriate conversational behaviour may not be shared across the Spanish-speaking world. Thus, while the use of usted might well be the unmarked form of address in Bogota, this is not necessarily the case in other Spanish-speaking cities, particularly in Montevideo where the incidence of tú in institutional contexts such as this one is commonplace (Márquez Reiter and Placencia 2004; Márquez Reiter and Stewart 2008).

As observed in the analysis of the call and of the interviews conducted with both conversational participants as well as with other agents of the call centre, the new economy, which is epitomized by the creation and proliferation of call centres, brings about new forms of communication. These new ways of communication, which are increasingly taking over more traditional intracultural face-to-face service encounters, require the recruitment of a highly qualified workforce as well as an awareness on the part of its customers that having access to services on a twenty-four hour a day seven days a week basis from the easy reach of one's telephone mean travelling cultural distances.

\section{Concluding remarks}

The foregoing conversational analysis represents a primary occasion for contact between a Bogotano and a Montevidean, who may otherwise only come in contact with one another through the media, the internet and/or tourism. The lack of contact between the Latin American nations to which the conversational participants belong goes back to colonial times (i.e. viceroyalty of New Granada v. viceroyalty of La Plata) and can also be explained, among other things, by their geographic position (i.e. north v. south of South America) as well as by their current economic membership and Latin American trading partners (i.e. The Andean Group v. Mercosur).

While sameness of language may, theoretically speaking, guarantee a general understanding, it does not necessarily involve sameness of meaning. Put differently, the rules which underpin the communicative behaviour of speakers of a language variety may not necessarily be shared by speakers of other varieties of the same language. This, in turn, may result in failure to communicate efficiently between speakers who share a broad language in common (i.e. Spanish) but come from different Spanish-speaking backgrounds. In this context, instances of communicative failure, as observed in the analysis of the call, are likely to be naïvely attributed to one or both of the conversational participants' attitudes or personalities rather than to cultural differences in what counts as language competence. Thus, our modern networked globalized economy, which is symbolized, among others, by the creation and migration of call centres, does not always bring about the 'death of distance'. On the contrary, the 'death of distance' may bring to the fore cultural dissimilarities in the participants' presumably shared background of their Latin American sub-culture.

The interactional misfires observed in the conversational exchange examined here principally stem from the different interpersonal and politeness orientations of the conversational participants. Specifically, the client's contributions were oriented towards 
the enactment of a respectful distance whereas those of the agent were oriented towards reducing both the physical distance (i.e. remote mediated communication) and social distance between her and the client. These differing orientations reflect different norms of what constitutes appropriate conversational behaviour in an institutional context such as this one: an unsolicited and primarily task-oriented call between strangers.

Potential interactional asymmetries of the kind discussed in this paper are ignored and further aggravated by the call centre's unsuccessful regulation of talk through the imposition of a code of conversational behaviour (i.e. in-house rules for making outbound calls) which is seen as alien and illogical by some of its agents (i.e. lack of surprise element in attempting an unsolicited sale). This results in the agents' deployment of their own instinctive and cultural conversational strategies (e.g. small talk, proffering of reason for the call once it has been established that the answerer is the called, etc.).

Alien as it may seem to some of its agents, the code of behaviour is aimed at protecting the company's face in remote faceless interactions. The code is essentially prescriptive in the sense that it assumes the importance of written Spanish in spoken interactions and over the vernaculars of its agents, as well as over some of the clients' own preferences. The way in which communication should unfold with clients is a means of exercising control over the style of the agents in an effort to present a standard homogeneous image of the company. This image, as observed by the recommended formality and some of the opening sequences (e.g. self and organizational identification, tailor-made formulation of the reason for the call) is reminiscent of primarily transactional calls in English. It could thus be claimed that it represents yet another type of corporate migration: the extrapolation of Western style communicative patterns to a non-Western context. In this sense, continuing social and economic control is exercised at both the micro and macro level. At the micro level this is seen by the script that agents should follow and at the macro level this is evidenced by the multinational's imposition of a developed Western style working model over ways of interacting and working in developing emerging economies.

Additionally, the fact that the agents of this call centre are in their vast majority highly educated and, in some cases, have more educational qualifications than the clients themselves may bring about a discourse of resistance, especially when faced with explicit demonstrations of unequal power, such as Dr Segundo's insistence on the formal pronoun. These are some of the power asymmetries they have to live with due to their own national socioeconomic development. Last but not least, given that only ten per cent of the business that could be offshored has so far been realised (NASSCOM McKinsey Report (1995)), it is likely that speakers of different varieties of Spanish will, in the not so distant future, be interacting with one another for a variety of business matters. In the increasingly capitalist globalized world in which we live, the potential for growth of the business process outsourcing industry and its impact on language and business communication is immense. Therefore it is crucial for companies to develop operating routines which are informed by the wealth of studies that have been undertaken on the communicative styles as well as the interpersonal and politeness orientations of the different cultures of both the company's clientele and its employees. This should be coupled with training courses for employees that focus on the minutiae of interaction rather than merely on technical knowledge.

\section{Notes}


${ }^{1}$ Castells' 'space of flows' refers to the material and immaterial components of the global information networks through which more and more of the economy is coordinated in real time across distances.

${ }^{2}$ Support for this can be found in the number of television adverts which proudly advertise the 'come back' of national call centres (see, for example, NatWest bank adverts in the UK and note the number of offshore call centres servicing US customers which have recently relocated to the US).

3 'Offshore call centre benefits challenged'. Retrieved on 21 December 2007 from www.ft.com

4 'National news: Barclaycard call centre jobs blow'. Retrieved on 21 December 2007 from www.ft.com

${ }^{5}$ Informal interviews with institutional representatives (i.e. telemarketing agents) were conducted during their breaks and in the call centre's transportation that collects/takes employees to/from their homes. Ten hours of recorded informal interviews were collected.

${ }^{6}$ It should be noted that the call centre also deals with clients from Brazil. To this end bilingual Portuguese-Spanish speakers are employed. In the case of the latter, bilingualism is seen as a commodity.

${ }^{7}$ For a recent treatment of localization in international business phone calls see Rasmussen Hougaard (2008).

${ }^{8}$ A case in point here is that of Bonaerense clients who recurrently request to be treated by vos and by their first names as the use of usted makes them 'feel old'. This information was gathered from interviews conducted with agents who work with Bonaerense clients and also figures in various calls within the database. It should be noted that this is also the case in some calls with clients from Caracas.

9 The Spanish pronominal system is pragmatically complex and varies across Latin America. In the Montevidean Spanish spoken by the agent, vos is generally employed in relationships where there is intimacy, tú in those where there is some confianza and usted in those relationships where tú may not be deemed appropriate, generally because the addressee is (much) older than the speaker and/or because there has been no previous contact between the participants. On the other hand, in the Bogotano Spanish spoken by the client usted is used in intimate and non-intimate relationships given that tú is generally associated with disdain. It should be noted, however, that research into the Spanish pronominal system is not conclusive and that the social norms which underlie its use change as society changes. We thus find claims to the effect that tú is employed by Bogotano youth, in particular by those who belong to the high class while older 
Bogotanos of the same social class prefer the use of usted in familial environments (Fontanella de Weingberg 1999).

10 Socialism is here understood in a broad and relative sense given that it was one of the traditional right-wing political parties, the Colorados, who set up the social welfare state.

11 It should be noted that in Mexican Spanish, the word licenciado is used to refer to lawyers as well as being a generally polite title. The company's records to which the agent had access to did not indicate whether Mr González was a lawyer or not. However, the lack of such title appears to have been interpreted by the client as both disrespectful and a controlling expression meant to communicate/convey the agent's power'.

\section{References}

Budach, G., Roy, S. and Heller, M. (2003) Community and commodity in French Ontario. Language in Society 32: 603-627.

Cairncross, F. (1997) The Death of Distance: How the Communication Revolution will Change our Lives. Boston, MA: Harvard Business Review.

Caffi, C. (1998) Metapragmatics. In J. Mey and R. Asher (eds) Concise Encyclopeadia of Pragmatics 581-586. Oxford: Elsevier.

Cameron, D. (2008) Talk from the top down. Language \& Communication 28: 143-155.

Castells, M. (1996) The Rise of the Network Society. Oxford and Malden, MA: Blackwell.

Daskal A. R. (1996) A framework and model for understanding Latin American and Latino/Hispanic cultural patterns. In D. Landis and R. Bhagat (eds) Handbook of Intercultural Training ( $2^{\text {nd }}$ edition) 327-348. Thousand Oaks, CA: Sage.

Fitch, K. (1991) A ritual for attempting leave-taking in Colombia. Research on Language and Social Interaction 24: 209-224.

Fontanella de Weinberg, M. B. (1999) Sistemas pronominales de tratamiento usados en el mundo hispánico. In I. Bosque and V. Demonte (eds) Gramática Despecriptiva de la Lengua Española 1399-1425. Madrid: Espasa.

Friginal, E. (2009) The Language of Outsourced Call Centers. A Corpus-based Study of Cross-cultural Interaction. Amsterdam: John Benjamins.

Giles, H., Coupland, J. and Coupland, N. (1991) Accommodation theory: Communication, context and consequence. In H. Giles, J. Coupland and N. Coupland (eds) Contexts of Accommodation: Developments in Applied Sociolinguistics 1-68. New York: Cambridge University Press. 
Gudykunst, W. (1998) Bridging Difference: Effective Intergroup Communication. Thousand Oaks, CA: Sage.

Hofstede, G. (2001) Culture's Consequences: Comparing Values, Behaviors, Institutions, and Organizations across Nations ( $2^{\text {nd }}$ edition). Thousand Oaks, CA: Sage.

Hutchby, I. (2001) Conversation and Technology. From the Telephone to the Internet. Cambridge: Polity Press.

King, K. (2009) Global connections: Language policies and international call centers. Language Policy 8: 1-87.

Linell, P. (1998) Approaching Dialogue: Talk, Interaction and Context in Dialogical Perspective. Amsterdam: John Benjamins.

Lipski, J. (1994) Latin American Spanish. London: Longman.

NASSCOM McKinsey. (2005) The NASSCOM McKinsey Study 2005. Retrieved on 15 July 2007 from www.nasscom.com

Márquez Reiter, R. (2005) Complaint calls to a caregiver service company: the case of desahogo, Intercultural Pragmatics 2: 481-513.

Márquez Reiter, R. (2006) Interactional closeness in service calls to a Montevidean carer service company. Research on Language and Social Interaction 39: 7-39.

Márquez Reiter, R. (2008) Intra-cultural variation: Explanations in service calls to two Montevidean service providers. Journal of Politeness Research 4: 1-29.

Márquez Reiter, R. (2009) How to get rid of a telemarketing agent? Face-work strategies in an intercultural service call. In F. Bargiela-Chiappini and M. Haugh (eds) Face, Communication and Social Interaction 55-77. London: Equinox.

Márquez Reiter, R. and Placencia, M. E. (2004) Displaying closeness and respectful distance in Montevidean and Quiteño service encounters. In R. Márquez Reiter and M. E. Placencia (eds) Current Trends in the Pragmatics of Spanish 121-155. Amsterdam: John Benjamins.

Márquez Reiter, R. and Placencia, M. E. (2005) Spanish Pragmatics. Basingstoke: Palgrave / MacMillan.

Márquez Reiter, R. and Stewart, M. (2008) Les interactions en site commercial à Montevideo et à Edimbourg: 'engagement' et 'considération envers autrui'. In C.Kerbrat-Orecchioni and V. Traverso (eds) Les Interactions en Site Commercial: Invariations et Variations 277-303. Lyon: Ens Editions. 
Ministerio de Educación Nacional de Colombia. Homepage. Retrieved on 1 July 2009 from www.mineducacion.gov.co

Ohmae, K. (ed.). (1995) The Evolving Global Economy: Making Sense of the New World Order. Boston, MA: Harvard Business Review Press.

Rasmussen Hougaard, G. (2008) Membership categorization in international phone calls. The importance of 'being international'. Journal of Pragmatics 40: 307-332.

Sacks, H. (1992) Lectures on Conversation (2 vols. ed. by G. Jefferson). Oxford: Blackwell.

Sacks, H., Schegloff, E. and Jefferson, G. (1974) A simplist systematics for the organization of turn-taking in conversation. Language 4: 696-735.

Schegloff, E. (1986) The routine as achievement. Human Studies 9: 111-151.

Scollon, R. and Scollon, S. (1981) Narrative, Literacy and Face in Interethnic Communication. Norwood, NJ: Ablex

Scott, M. and Lyman, S. (1968) Accounts. American Sociological Review 33: 46-62.

Taylor, P. and Bain, P. (2005) 'India calling to the far away towns': The call centre labour process and globalization. Work, Employment and Society 19(2): 261-282.

Thomas, J. (1985) The language of power. Journal of Pragmatics 9: 765-783.

Tyler, A. (1995) The co-construction of cross-cultural miscommunication: Conflicts in perception, negotiation and enactment of participant roles and status. Studies in Second Language Acquisition 17: 129-152.

Zimmerman, K. and de Granda G. (eds). (2004) I. Sección temática: El español con otras lenguas. Revista Internacional de Lingüística Iberoamericana 2: 9-145.

\section{Appendix A: Transcription conventions}


- $\quad$ indicates a cut off of the prior word or sound

'underscoring' indicates emphasis

$\because: \quad$ indicates pitch rise

'volume' is indicated with capital letters

indicates falling intonation

? indicates rising intonation

, continuing intonation

( ) indicates that no hearing could be achieved for the talk or item

(0.3) numbers in parentheses indicate silence represented in tenths of a second

\section{Appendix B: Grammatical glosses}

T/V indicates the use of the familiar second person singular tú and/or vos

$\mathrm{U} \quad$ indicates the use of the unfamiliar second person singular usted 